\title{
Features of meteorological events preserved in a high- resolution Law Dome (East Antarctica) snow pit
}

\author{
AlisonJ. MaMORROW, ${ }^{1}$ Mark A. J. GURRAn, ${ }^{2}$ Tas D. VAN OMMEN, ${ }^{2}$ Vin I. MORGAN, ${ }^{2}$ \\ IAN ALLISON ${ }^{2}$ \\ ${ }^{1}$ IASOS and Antarctic CRC, Box 252-77 Hobart, Tasmania 7001, Australia \\ ${ }^{2}$ Antarctic CRC and Australian Antarctic Division, Box 252-80 Hobart, Tasmania 7001, Australia \\ E-mail:mark.curran@utas.edu.au
}

\begin{abstract}
Snow-pit and shallow firn-core records of oxygen isotope ratios $\left(\delta^{18} \mathrm{O}\right)$ and trace ion species were generated at a high-accumulation site on Law Dome, East Antarctica. Concordance between accumulation events identified in records up to $7.7 \mathrm{~km}$ apart confirms that the observed glaciochemical variations are the result of regional rather than local surface effects. This allows calibration of the snow-pit records with measured meteorological parameters. Net accumulation periods that comprise the snow-pit record are identified using hourly snow-accumulation measurements from a co-located automatic weather station (AWS). Particular focus is given to three net accumulation periods preserved during austral summer 1999/2000 that correspond to the top $0.5 \mathrm{~m}$ of the snow pit. Local meteorological conditions recorded during the summer accumulation periods by the AWS are combined with regional and synoptic-scale meteorology derived from Casey station (110 km away) and Advanced Very High Resolution Radiometer satellite imagery to identify potential source regions for chemical signals preserved in summer snow at Law Dome.
\end{abstract}

\section{INTRODUCTION}

Polar ice-core records have proven to be valuable tools for palaeoclimate reconstruction, recording both anthropogenic and natural global climate change (e.g. Benoist and others, 1982; Dansgaard and Oeschger, 1989; Mayewski and others, 1994). Information about past climate conditions is preserved as particles and air bubbles entrapped in the ice matrix, absorbed gases, dissolved trace-ion species and in the isotopic composition of the ice. However, our ability to interpret these ice-core signals is limited by difficulties in understanding the relative importance of changes in the source, transport and deposition processes that influence a precipitating air mass. Current research is directed towards this issue by comparing high-resolution, recently deposited glaciochemical records with contemporaneous meteorological observations (Hardy and others, 1998; Vuille and others, 1998; McMorrow and others, 2001).

The research described in this paper extends the preliminary analysis technique reported in McMorrow and others (2001) where shallow firn-core records from Law Dome, East Antarctica, were directly compared with local, regional and synoptic meteorological observations. The climatology of the Dome Summit South (DSS) drilling site on Law Dome (Fig. 1; Curran and others, 2002) indicates it is an ideal site for highresolution studies of the snowpack. The high annual accumulation $\left(0.7 \mathrm{~m} \mathrm{a}^{-1}\right.$ ice equivalent), low mean summer temperatures $\left(-12.6^{\circ} \mathrm{C}\right)$ and absence of frequent high wind gusts leads to the deposition of thick annual layers and ensures limited disturbance of the chemical archive (Morgan and others, 1997; McMorrow and others, 2001).

Moreover, seasonal characteristics of the synoptic-scale meteorology influencing the region allow a comprehensive examination of the impact of meteorological conditions on glaciochemical signals. For example, it is well documented that the Law Dome region is influenced by generally intensified cyclonic activity during the austral winter months (June-August) and a semi-annual variation in atmospheric pressure, with minima in the austral spring (September-November) and autumn (March-May) (Schwerdtfeger, 1984; Allison and others, 1993; Jones and Simmonds, 1993; King and Turner, 1997).

This paper presents preliminary results from techniques by which trace chemical and oxygen isotope ratio $\left(\delta^{18} \mathrm{O}\right)$ records in snow pits and firn cores, collected between 20 February and 6 March 2000, are directly compared with observed meteorological conditions. Glaciochemical records are examined on spatial scales ranging from $30 \mathrm{~cm}$ up to $7.7 \mathrm{~km}$ in order to identify regional accumulation events. High-resolution snow-accumulation data measured by a co-located automatic weather station (AWS) are used to identify the meteorological events that comprise the snow-pit records. The top $0.5 \mathrm{~m}$ of the snow-pit records is then compared with meteorological conditions during the most recent summer period (summer 1999/2000).

\section{METHODS AND SAMPLE COLLEGTION}

The results presented here draw on material from a 2 m deep snow pit (Rama) and four shallow (6 m) firn cores located up to $7.7 \mathrm{~km}$ apart from near the DSS drilling site on Law Dome (Fig. 1; Curran and others, 2002). The snow pit and firn cores are located on the accumulation isopleth that crosses DSS (approximately $640 \mathrm{~kg} \mathrm{~m}^{-2} \mathrm{a}^{-1}$ ) in order to minimize accumulation scaling differences between drilling sites. 

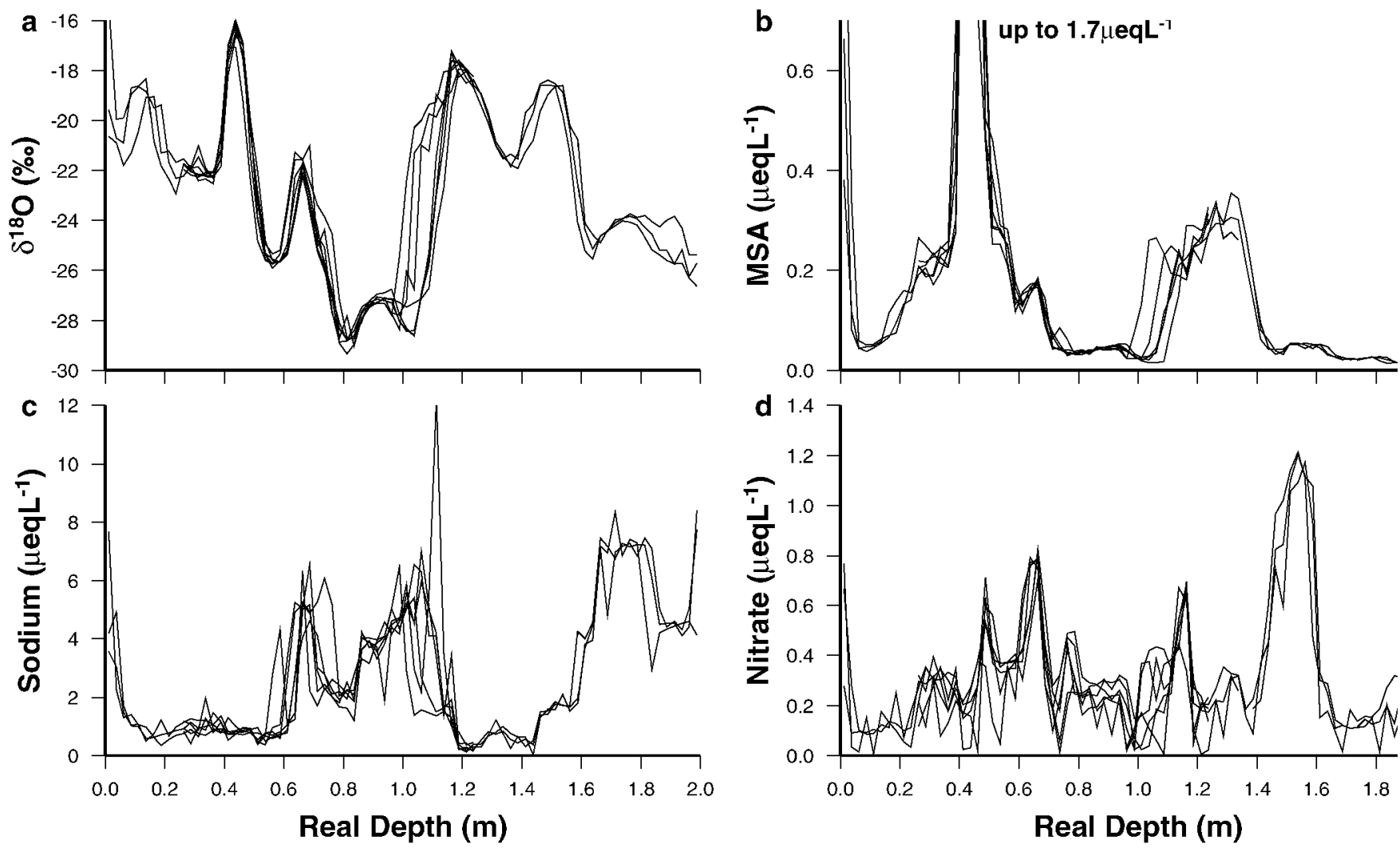

Fig. 1. Seven-line intra-pit comparisons for the Rama snow pit. (a) $\delta^{\not B} O$, , (b) MSA, (c) sodium, (d) nitrate.

The snow pit was sampled using clean techniques to allow the extraction of trace-ion samples free from contamination. All instruments used in the digging and sampling of the snow pits were washed with deionized Milli-Q water (resistivity $>18 \mathrm{M} \Omega-\mathrm{cm}$ ) prior to transportation to the field. Snow-pit personnel wore clean suits, at least two sets of plastic gloves and dust masks to minimize contamination from human interference. Initial digging of the snow pit to approximately $1 \mathrm{~m}$ depth was done using cleaned stainless-steel shovels. A further $20 \mathrm{~cm}$ of the wall was removed with a number of scrapers to ensure an uncontaminated sampling wall. Just before sampling, a further $2 \mathrm{~cm}$ was scraped away using a clean microtome blade. A cleaned metal template was then fastened to the wall using steel pins, and two samples for each depth interval were extracted using steel square tube probes. Sample resolution was $2.5 \mathrm{~cm}$, and the template ensured millimetre depth accuracy. Samples were collected for $\delta^{18} \mathrm{O}$ and traceion chemical species (magnesium, sodium, potassium, calcium, nitrate, sulphate, methanesulphonic acid (MSA) and chloride). The digging and sampling process was then repeated for the 1-2 $\mathrm{m}$ depth interval. Seven lines of samples (approximately $30 \mathrm{~cm}$ apart) were collected from the snow pit: three lines from 0 to $2 \mathrm{~m}$ and four lines covering a depth range $0.25-1.25 \mathrm{~m}$.

Several shallow firn cores $(6 \mathrm{~m})$ were collected within approximately $0.5 \mathrm{~m}$ of the snow-pit wall, and at regular intervals along the north/south accumulation isopleth that crosses DSS. All cores were collected with a hand auger, with special care taken to preserve the top $0.3 \mathrm{~m}$ section of friable material. Firn cores and snow-pit samples were transported frozen back to Australia for decontamination, sampling and analysis of $\delta^{18} \mathrm{O}$, trace-ion chemical species and hydrogen peroxide at $2.5 \mathrm{~cm}$ resolution using established techniques (Curran and Palmer, 2001; McMorrow and others, 2001).

\section{SPATIAL REPRODUCIBILITY OF GLACIO- CHEMICAL SIGNALS}

Snow-pit and firn-core comparisons are made at various scales across Law Dome to assess the spatial reproducibility of signals and to identify regional accumulation events preserved in the snowpack. Regional accumulation events are recorded at different depths in snow-pit or firn-core records due to accumulation differences between sites, different sampling/drilling dates, loss of surface snow at the time of sampling/drilling, surface snow redistribution by wind, surface irregularity, and local firn-density variations. Despite these effects, there is excellent agreement in multiple trace-ion and $\delta^{18} \mathrm{O}$ records at both the intra-pit scale (Fig. 1) and the inter-core scale (Fig. 2). The seven-line intra-pit comparison highlights the minimal impact that surface irregularities (sastrugi and dunes) over spatial scales from $30 \mathrm{~cm}$ to approximately $2 \mathrm{~m}$ has on the snow-pit records (Fig. 1). Major features in the trace-ion and $\delta^{18} \mathrm{O}$ records are represented in all or most of the sample lines, indicating regional accumulation events that can be used in the meteorology comparison. The $\delta^{18} \mathrm{O}$ and MSA records show very good agreement at this spatial scale; in contrast, sodium shows greater spatial variability when concentrations are high. These results are consistent with results reported by Steffensen and others (1996). However, in contrast to Steffensen and others (1996), nitrate profiles presented here show considerable variability when concentrations are low, but good agreement when concentrations are higher.

At Law Dome, $\delta^{18} \mathrm{O}$, MSA and nitrate concentrations peak in the summer period, and sea salts (indicated by sodium) generally peak in winter (Curran and others, 1998a). A clear seasonal signal can be seen for $\delta^{18} \mathrm{O}$, MSA, nitrate and sodium in the snow pit over two annual cycles, with summer species peaking around 0.5 and $1.3 \mathrm{~m}$ and 


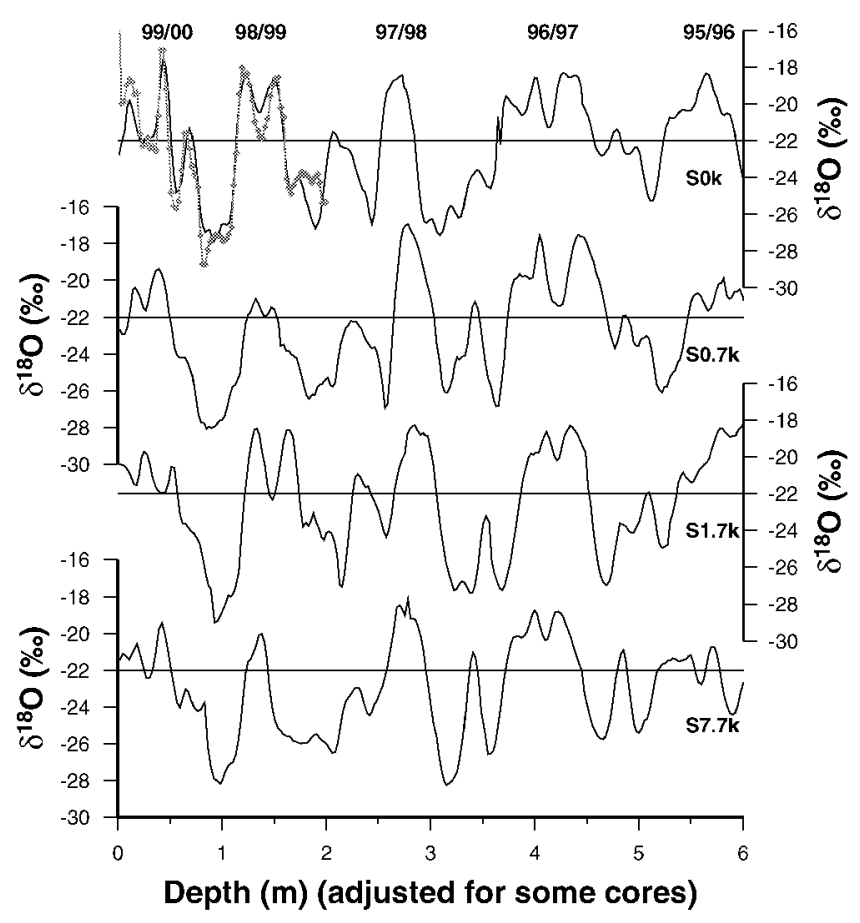

Fig. 2. Inter-core $\delta^{18} \mathrm{O}$ comparisons from drilling sites. Top to bottom: SOk (co-located with the Rama snow pit; Rama $\delta^{18} \mathrm{O}$ record is shown as dotted line), $S 0.7 \mathrm{k}(0.7 \mathrm{~km}$ south of Rama), $S 1.7 k$ (1.7 km south of Rama), $S 7.7 \mathrm{k}(7.7 \mathrm{~km}$ south of Rama). The depth scale for $S 0.7 \mathrm{k}$ was adjusted due to the earlier drilling date of this core.

winter species peaking around 0.9 and $1.7 \mathrm{~m}$ (Fig. 1). It is interesting to note that all species show high concentrations at the very surface of the snow pit, corresponding to late February 2000. This event is discussed in detail later in the paper. In addition to seasonal cycles, the $2.5 \mathrm{~cm}$ sample resolution at this high-accumulation site has captured many sub-seasonal phenomena (e.g. multiple $\delta^{18} \mathrm{O}$ peaks during summer deposition, non-summer elevated levels of MSA, and double peaks in winter sodium levels (Fig. 1)).

Comparisons between $\delta^{18} \mathrm{O}$ records over spatial scales of up to $7.7 \mathrm{~km}$ also show excellent agreement (Fig. 2). These inter-core comparisons are used to identify regional events in the firn-core records and to assess the spatial reproducibility of signals preserved at different drilling sites on Law Dome. The depth of accumulation events in the core record is influenced by different drilling dates of the cores, accumulation differences between drilling sites, surface irregularity caused by sastrugi and the rapid density changes in the top layers of the snowpack. Accumulation differences between sites were minimized by drilling along the same accumulation isopleth, and drilling-date differences were minimized by drilling within a 16 day window. Figure 2 shows that seasonal and major sub-seasonal signals are preserved in all cores, allowing the identification of regional events for further analysis and comparison with meteorological conditions.

\section{IDENTIFICATION OF METEOROLOGICAL EVENTS}

Meteorological events that make up the snow-pit and firncore records are identified using snow accumulation recorded by the AWS, located 50 m west of the Rama snow pit. The AWS measured snow height using an ultrasonic sounding at hourly intervals. Net accumulation is calculated as the difference between snow-accumulation and snow-removal events, as recorded by the AWS (Fig. 3). The most notable feature of Figure 3 is the difference in seasonal net accumulation during 1998 (Julian days (1998) 0-365) compared to 1999 (Julian days 366-730). The seasonal distribution of net accumulation during 1998 is relatively even, with each calendar season receiving approximately equal

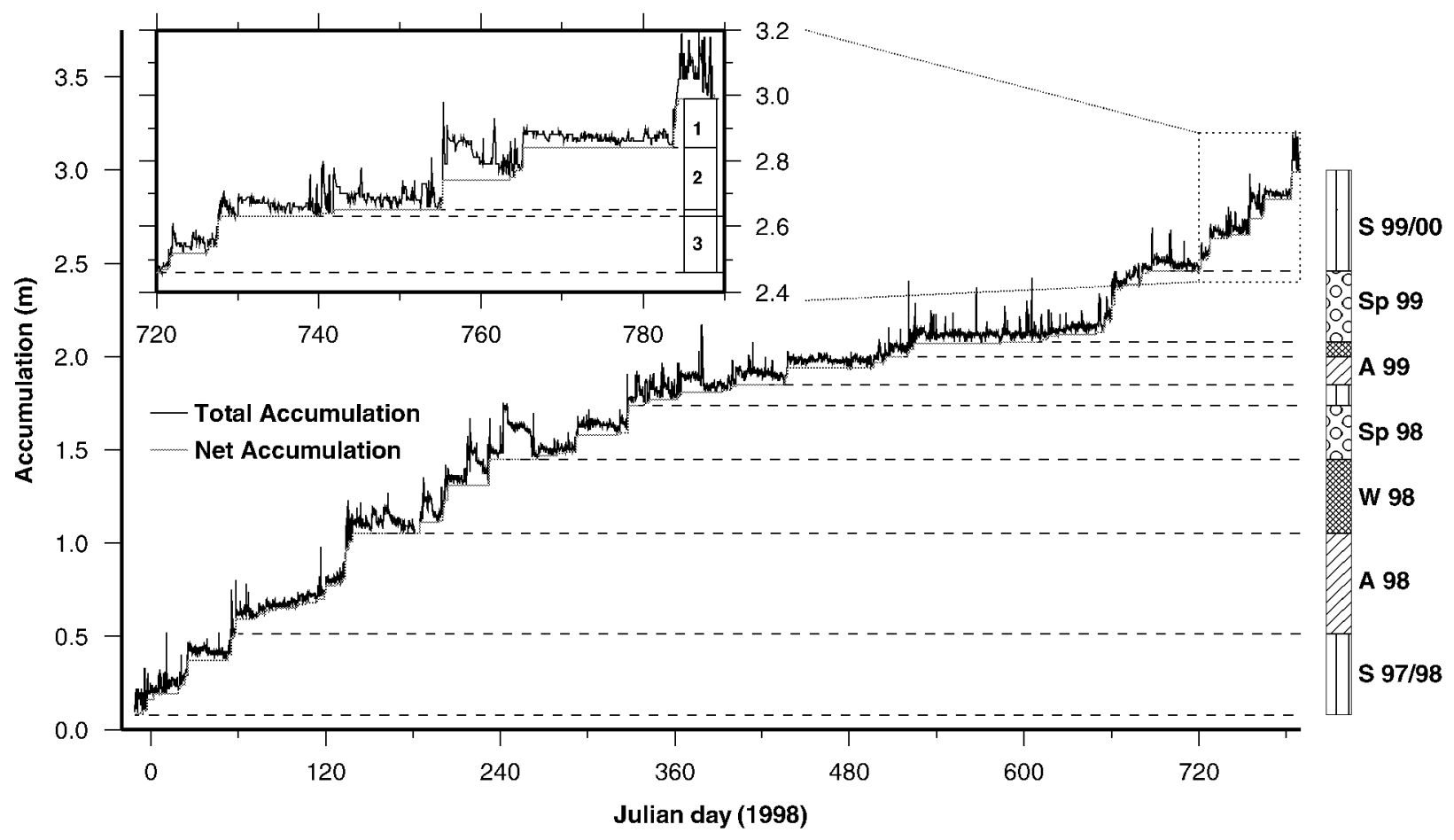

Fig. 3. Total and net accumulation recorded from the AWS from 21 December 1997 (Julian day -10) to 27 February 2000 (Fulian day 788). Net accumulation from each austral season is shown ( $\operatorname{summer}(S)$, autumn $(A)$, winter $(W)$, spring (Sp) ), and accumulation periods (P1-P3) from summer 1999/2000 are also illustrated. 


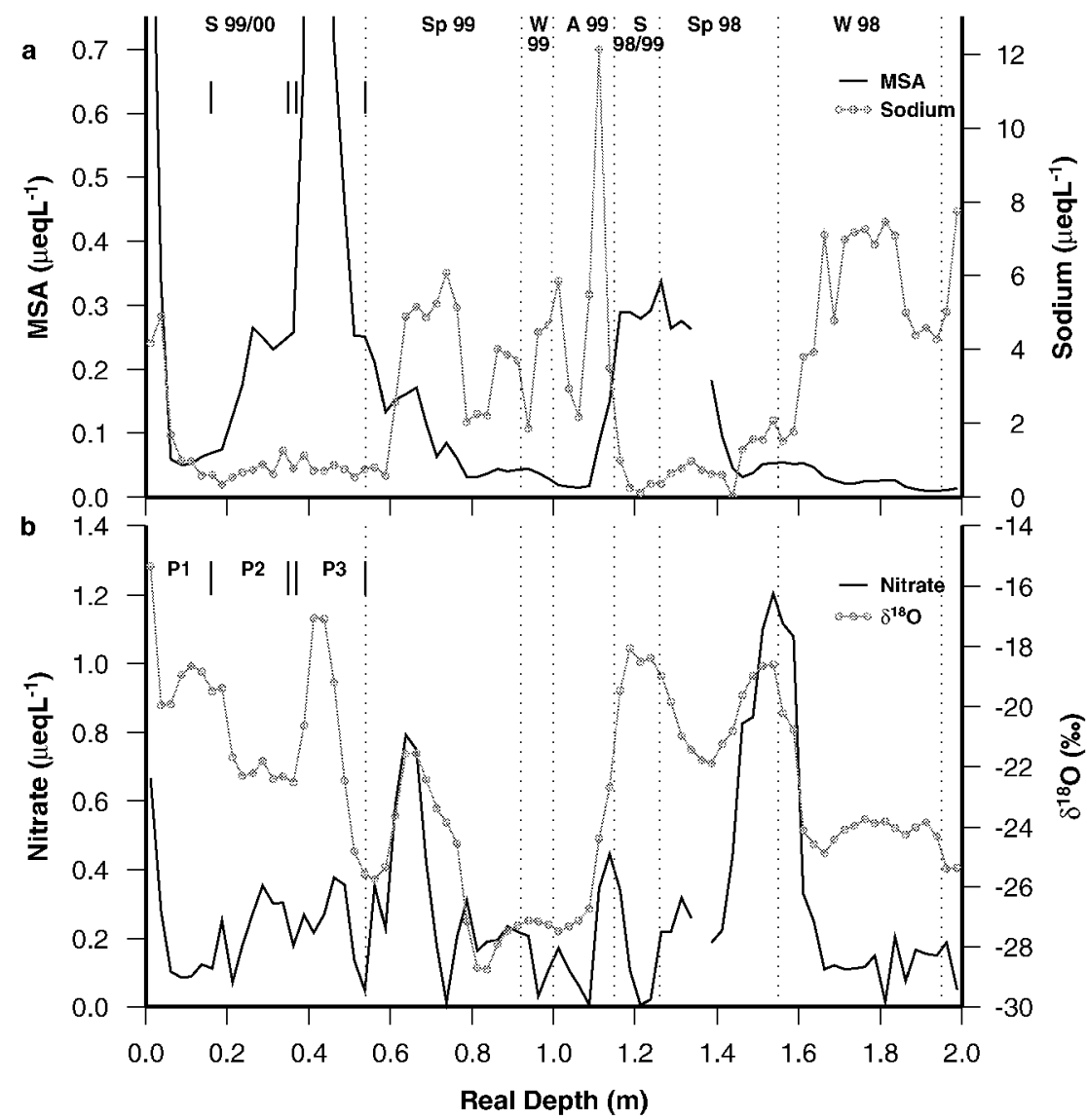

Fig. 4. Glaciochemical records from a representative line from Rama, with preliminary dating scale illustrated. (a) MSA and sodium, (b) nitrate and $\delta^{18} \mathrm{O}$. Dotted lines indicate austral season boundaries defined by the AWS net accumulation record (not corrected for densification effects). Period boundaries for summer 1999/2000 (P1-P3) are also illustrated.

amounts of net snowfall (average $0.42 \mathrm{~m}$ per season). However, from summer 1998/99 through to early spring 1999 (Julian days 360-655) the AWS recorded limited net snow accumulation (summer 1998/99, 0.11 m; autumn 1999, $0.15 \mathrm{~m}$; winter 1999, $0.08 \mathrm{~m})$. Snow accumulation began to increase during spring 1999 (0.38 $\mathrm{m})$ and into summer 1999/ $2000(0.53 \mathrm{~m})$ (Julian days 655-780). These results highlight interannual accumulation variability and have clear implications for interpreting longer ice-core records.

Difficulties arise in registering the AWS accumulation depth scale (Fig. 3) with the snow-pit records due to densification effects. The accumulation sensor is mounted on a mast supported by a fixed baseplate that is buried approximately $0.6 \mathrm{~m}$ below the surface at the start of the observation periods (when the AWS was installed or re-installed). Gradual densification of this material between sensor and baseplate at the start of the accumulation period acts to lower the surface height registered by the sensor. This leads to an underestimate of accumulated material and an apparent "shortening" of the firn column height as reported by the AWS over the observation period. Similarly, material deposited during the observation period is compressed, distorting the timedepth relationship inferred from the AWS scale (Fig. 3).

The degree of record-shortening by compaction during the observation period has been estimated here assuming Sorge's law (a steady-state density profile) and experimenting with different empirical density profiles. The baseplate depth changes from $0.6 \mathrm{~m}$ to $1.84 \mathrm{~m}$ during the most recent observation period (December 1998-February 2000). Compression of the $0.6 \mathrm{~m}$ layer over this depth range varies from 4 to $6 \mathrm{~cm}$ depending upon the assumed density profile. The low estimate arises from a density model which fits the overall DSS profile extremely well (Van Ommen and others, 1999), but which may not capture changes in the upper few tens of centimetres of firn. The higher estimate arises if the previous model is altered to include a rapid (exponential) densification in the upper $0.5 \mathrm{~m}$ from a nominal surface density of $350 \mathrm{~kg} \mathrm{~m}^{-3}$.

For the purposes of this paper, densification effects are not treated any further, and detailed temporal registration is confined to the uppermost portion of the records where the effects can largely be neglected. Development of this work, comparing measured densities and using observed ties between AWS data and snow-pit signals, should provide data that can be used to develop a refined model of densification in the future.

\section{EXAMINATION OF REGENT AGCUMULATION PERIODS}

The AWS net accumulation record indicates three main periods of net accumulation in the Rama snow pit for summer 1999/2000 (P1-P3) (Fig. 3). The corresponding glaciochemical signals are represented in Figure 4. Densification effects, as noted above, may lead to small shifts in the period boundaries represented in Figure 4. For this reason, the following analysis is restricted to the major changes in this recent portion of the record.

All three of the net accumulation periods preserved similar amounts of accumulated material $(0.16-0.19 \mathrm{~m})$ (Fig. 3; Table 1) yet quite different glaciochemical signals 
Table 1. Intercomparison of snow-pit signals and meteorological conditions for summer accumulation periods 1, 2 and 3 preserved in the Rama snow pit

\begin{tabular}{|c|c|c|c|}
\hline Period & $P 1$ & $P 2$ & P3 \\
\hline Dates & 22-27 Feb. 2000 & 25 Jan. 1999 to 4 Feb. 2000 & 21-28 Dec. 1999 \\
\hline Julian days (1998) & $783-788$ & $755-765$ & $720-727$ \\
\hline Net accumulation $(\mathrm{m})$ & 0.17 & 0.19 & 0.16 \\
\hline Snow-pit signal & $\begin{array}{l}\text { Co-deposition of MSA, } \delta^{18} \mathrm{O}, \\
\text { sodium }\end{array}$ & $\begin{array}{l}\text { Average summer signals, no distinct } \\
\text { peaks }\end{array}$ & $\begin{array}{l}\text { Narrow and pronounced MSA and } \\
\delta^{18} \mathrm{O} \text { peaks }\end{array}$ \\
\hline Local pressure & Two sharp troughs & Sharp trough & Two sharp troughs \\
\hline Local air temperature & Steady at $-12^{\circ} \mathrm{C}$ & $-11^{\circ}$ to $-17^{\circ} \mathrm{C}$ (variable) & Sharp rise from $-22^{\circ} \mathrm{C}$ to $-2^{\circ} \mathrm{C}$ \\
\hline Local wind speed & Sharp peak $\left(20.6 \mathrm{~m} \mathrm{~s}^{-1}\right)$ & Two sharp peaks (19.9 and $22.2 \mathrm{~m} \mathrm{~s}^{-1}$ ) & Two sharp peaks (24.9 and $14.5 \mathrm{~m} \mathrm{~s}^{-1}$ ) \\
\hline Local wind direction & Easterly & Variable, but tending easterly & Easterly and tending northerly \\
\hline Synoptic-scale meteorology & Large cyclonic system & Weak and disorganized cloud systems & Two large cyclonic systems \\
\hline Approx. source of system (s) & $45^{\circ} \mathrm{S}, 90^{\circ} \mathrm{E}$ & $55^{\circ} \mathrm{S}, 90^{\circ} \mathrm{E}$ & $55^{\circ} \mathrm{S}, 70^{\circ} \mathrm{E}$ \\
\hline
\end{tabular}
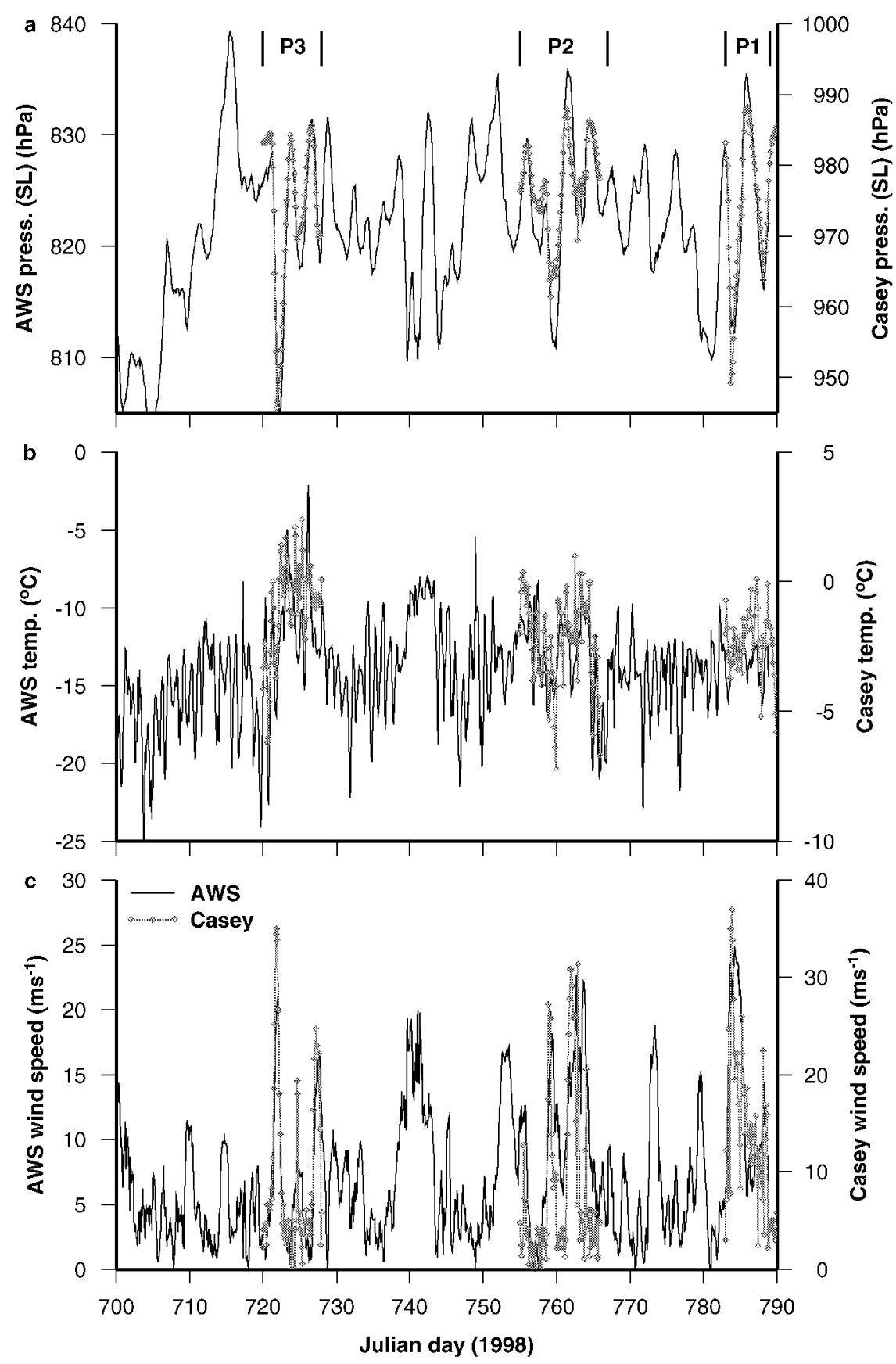

Fig. 5. Local meteorological conditions recorded by the AWS from 1 December 1999 (Julian day 700) to 27 February 2000 (Fulian day 788). (a) Station-level (SL) pressure, (b) air temperature, (c) wind speed. Net accumulation periods (P1-P3) are illustrated, and meteorological conditions recorded at Casey station during accumulation periods are also plotted. 

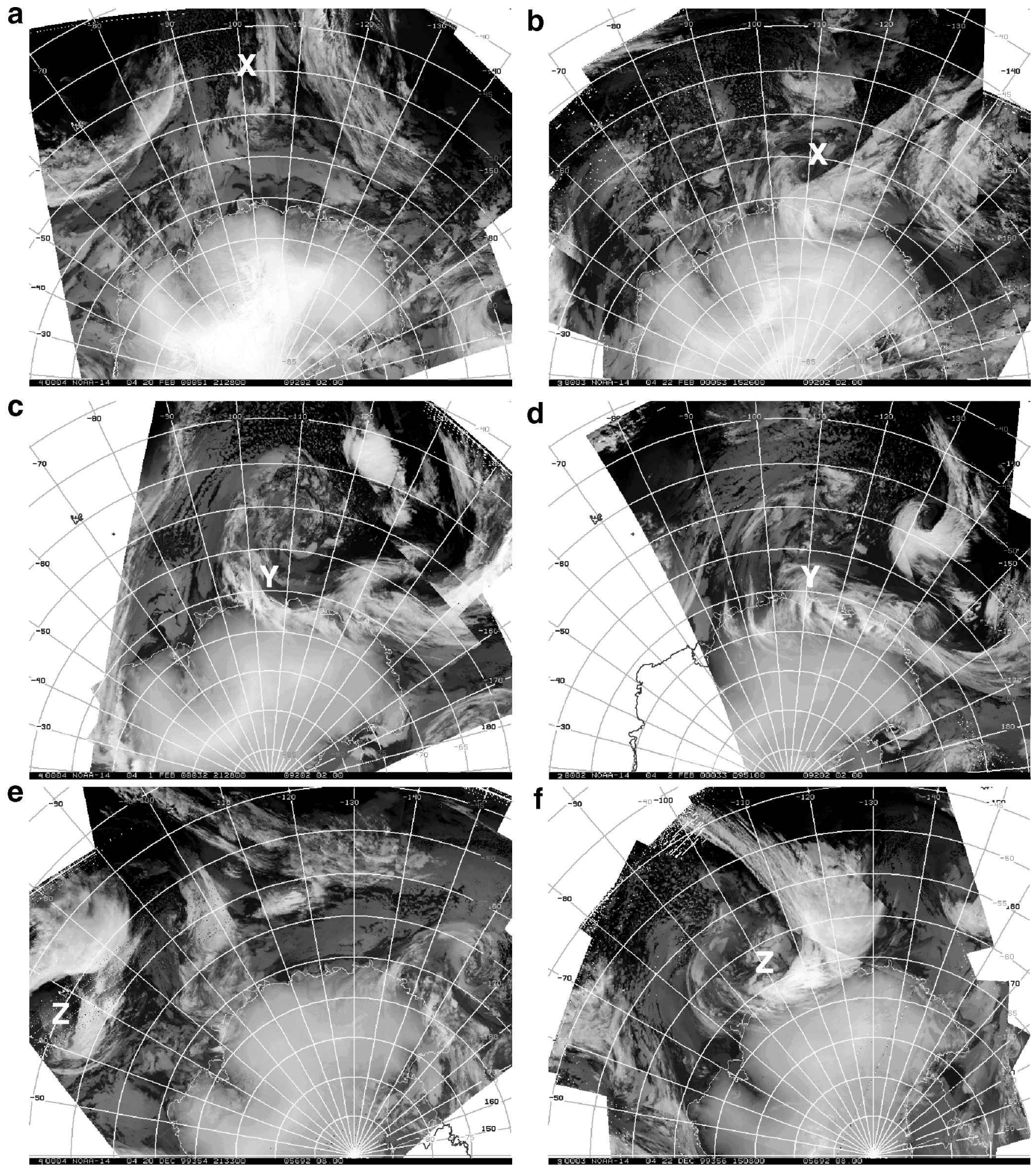

Fig. 6. AVHRR satellite imagery showing cyclonic systems associated with net accumulation periods $P 1(a, b), P 2(c, d)$ and $P 3$ (e,f): (a) X at 2128 UTC 20 February 2000 (Julian day 781); (b) X at 1526 UTC 22 February 2000 (Julian day 783); (c) Y at 2128 UTC 1 February 2000 (Julian day 762); (d) Yat 0951 UTC 2 February 2000 (Julian day 762); (e) Zat 0148 UTC 21 December 1999 (Julian day 720); (f) Z at 1508 UTC 22 December 1999 (Julian day 721).

(Fig. 4; Table 1). The snow-pit signals associated with P1 (late summer) include elevated levels of MSA, $\delta^{18} \mathrm{O}$, sodium and nitrate concentrations. The deposition of MSA with $\delta^{18} \mathrm{O}$ and sea salts outside the mid-summer MSA peak is also observed in deeper records at DSS (Curran and others, 2002). The snow-pit signals preserved during $P 2$ show levels of MSA, nitrate, $\delta^{18} \mathrm{O}$ and sodium comparable to average summer concentrations at DSS with no distinct peaks. In contrast, P3 has preserved a very narrow and pronounced peak in MSA and $\delta^{18} \mathrm{O}$, with MSA concentrations peaking at $1.7 \mu \mathrm{eq} \mathrm{L}^{-1}$, which is higher than average summer levels from deeper records at DSS $\left(0.07-0.25 \mu \mathrm{eq} \mathrm{L}^{-1}\right)$

Local meteorological conditions recorded by the AWS during summer 1999/2000 are illustrated in Figure 5. The accumulation periods are all marked by a sharp decline in atmospheric pressure and pronounced peaks in wind speed 
(Fig. 5). There is also evidence of elevated temperatures during net accumulation periods, especially for $\mathrm{P} 3$. In addition, these conditions are reflected in the meteorology at Casey station (located $110 \mathrm{~km}$ from DSS), indicating the influence of largescale atmospheric systems. Precipitation events at Law Dome are usually caused by the passage of cloud bands associated with cyclonic systems over the ocean to the north, and resulting in strong easterly winds, falling atmospheric pressure and elevated temperatures (Schwerdtfeger, 1984; Callaghan and Betts, 1987; Bromwich, 1998). The conditions recorded by the AWS and Casey station during the net accumulation periods are consistent with these findings.

There is also a period (Julian days 738-743) in the summer record where the AWS measured conditions similar to the net accumulation periods (Fig. 5), yet only $0.02 \mathrm{~m}$ of accumulation was retained in the record (Fig. 3). Significant snowfalls are recorded during this period, but the majority of material was lost through wind scouring (Fig. 3). This is consistent with the sustained high levels of wind speeds recorded by the AWS, in contrast to the other net accumulation periods which are characterized by sharp spikes in wind speed (Fig. 5).

Advanced Very High Resolution Radiometer (AVHRR) infrared imagery illustrates differences in source and transport mechanisms influencing each of the accumulation periods (Fig. 6, Table 1). All periods were characterized by cyclonic systems passing over Law Dome, yet the intensity, travel path and speed of travel of the cyclones varied between periods. $\mathrm{Pl}$ is characterized by a large cyclonic system that began to develop on 20 February 2000 (Julian day 781) around $45^{\circ} \mathrm{S}, 90^{\circ} \mathrm{E}$ (Fig. $6 \mathrm{a}$ ) and then intensified and moved due south onto Law Dome early on 22 February 2000 (Julian day 783) (Fig. 6b). This system continued to influence Law Dome until around 27 February 2000 (Julian day 788). P2 is characterized by weak and disorganized cyclonic systems that decayed quickly while passing over Law Dome throughout the period. An example of one of these systems is given in Figure $6 \mathrm{c}$ and $\mathrm{d}$. In contrast, AVHRR imagery for P3 shows two large cyclonic systems passing over Law Dome in quick succession. System 1 is sourced from the Heard/McDonald Island region $\left(55^{\circ} \mathrm{S}, 70^{\circ} \mathrm{E}\right)$ around 20 December 1999, and travelled southeast and onto Law Dome on 22 December 1999 (Julian day 721) (Fig. 6e and f). System 2 followed a similar path, and passed over Law Dome on 27 December 1999 (Julian day 726), although cloud cover indicates a less intense system (not shown).

The late-summer deposition of MSA, $\delta^{18} \mathrm{O}$ and sea salts preserved during $\mathrm{Pl}$ can be explained by the rapid poleward transport of a strong cyclonic system from mid-latitudes (Table 1). Rapid advection of warm marine air from midlatitudes, where there is an expected source of DMS from marine biota at this time of year (Curran and Jones, 2000), provides an explanation for the enhanced MSA concentrations in the snow-pit record. Limited fractionation of $\delta^{18} \mathrm{O}$ due to the short time available for precipitation and increased uptake of sea salts during rapid transport of warm air masses explains the high levels of $\delta^{18} \mathrm{O}$ and sodium in the snow-pit record. The average summer levels of MSA, $\delta^{18} \mathrm{O}$, nitrate and sodium preserved during $\mathrm{P} 2$ are the result of weak cyclonic systems passing in close succession during this period. These systems all developed in close proximity to Law Dome (Table 1), with systems passing over the sea ice before reaching Law Dome. The sea-ice zone is an important source of MSA for summer deposition at Law Dome
(Gurran and Jones, 2000), and the low sodium concentrations can be explained by limited sea-salt aerosol production associated with these weak systems. In contrast, the enhanced mid-summer levels of MSA preserved during P3 may be sourced from the Heard/McDonald Island region where DMS productivity from marine biota is extremely high (Table 1) (Curran and others, 1998b).

\section{GONGLUDING REMARKS}

This paper presents preliminary results from ongoing research aimed at increasing our understanding of the link between ice-core signals and climate conditions. The comparison of net accumulation between two successive years, where 1998 recorded relatively uniform accumulation throughout the year, and 1999 recorded varied amounts of net accumulation throughout the year, highlights interannual accumulation variability and has implications for interpreting the deep ice-core record (e.g. ice-core dating, seasonality studies). Particular examination of the accumulation periods that comprise summer 1999/2000 reveals variable meteorological conditions for specific snow-pit signals. Late-summer deposition of MSA, $\delta^{18} \mathrm{O}$ and sea salts is associated with rapid advection of air from low latitudes where DMS production is high at this time of year. This allows identification of a potential source region for non-summer elevated levels of MSA (see Curran and others, 2002) observed in deeper ice-core records at DSS. In addition, a pronounced mid-summer MSA peak, higher than concentrations observed in deeper records at DSS, is associated with strong cyclonic systems sourced from a known area of high DMS production. In contrast, average summer levels of MSA, $\delta^{18} \mathrm{O}$ and sodium are associated with weak cyclonic development close to the Law Dome region. These results highlight the effects of circulation patterns on the snow-pit record. Deep ice-core records from coastal Antarctic sites influenced mainly by the procession of cyclonic systems are likely to be sensitive to changes in circulation patterns through the palaeoclimate record. This three-period comparison provides some insight into source and transport paths influencing summer snow-pit signals, and enhances our understanding of similar signals preserved in deeper ice-core records at Law Dome.

\section{AGKNOWLEDGEMENTS}

The authors would like to thank the Trans-Antarctic Association for providing financial assistance to attend the International Symposium on Ice Cores and Climate. Thanks also to the 1999/2000 Law Dome field party for assistance in sample collection.

\section{REFERENCES}

Allison, I., G. Wendler and U. Radok. 1993. A climatology of the East Antarctic ice sheet $\left(100^{\circ} \mathrm{E}\right.$ to $\left.140^{\circ} \mathrm{E}\right)$ derived from automatic weather stations. $\mathcal{F}$. Geophys. Res., 98(D5), 8815-8823.

Benoist, J. P., J. Jouzel, C. Lorius, L. Merlivat and M. Pourchet. 1982. Isotope climatic record over the last $2.5 \mathrm{ka}$ from Dome C, Antarctica, ice cores. Ann. Glaciol., 3, 17-22.

Bromwich, D. H. 1988. Snowfall in high southern latitudes. Rev. Geophys, 26(1), 149-168.

Callaghan, J. and M. Betts. 1987. Some cases of westward moving disturbances in the Mawson-Davis area, Antarctica. Austral. Meteorol. Mag., $35(2), 79-85$ 
Curran, M. A. J. and G. B. Jones. 2000. Dimethyl sulfide in the Southern Ocean: seasonality and flux. F. Geophys. Res., 105(D16), 20,451-20,459.

Curran, M. A. J. and A. S. Palmer. 2001. Suppressed ion chromatography methods for the routine determination of ultra low level anions and cations in ice cores. F. Chromatogr., Ser. A, 919(1), 107-113.

Curran, M. A. J., T. D. van Ommen and V. Morgan. 1998a. Seasonal characteristics of the major ions in the high-accumulation Dome Summit South ice core, Law Dome, Antarctica. Ann. Glaciol., 27, 385-390.

Curran, M. A. J., G. B. Jones and H. Burton. 1998b. The spatial distribution of DMS and DMSP in the Australasian sector of the Southern Ocean. $\mathcal{F}$. Geophys. Res., 103(D13), 16,677-16,689.

Curran, M. A. J. and 6 others. 2002. Post-depositional movement of methanesulphonic acid at Law Dome, Antarctica, and the effect on accumulation rate. Ann. Glaciol., 35 (see paper in this volume).

Dansgaard, W. and H. Oeschger. 1989. Past environmental long-term records from the Arctic. In Oeschger, H. and C. C. Langway, Jr, eds. The environmental record in glaciers and ice sheets. Chichester, etc., John Wiley and Sons, 287-318.

Hardy, D. R., M. Vuille, C. Braun, F. Keimig and R.S. Bradley. 1998. Annual and daily meteorological cycles at high altitude on a tropical mountain. Bull. Am. Meteorol. Soc., 79(9), 1899-1913.

Jones, D. A. and I. Simmonds. 1993. A climatology of Southern Hemisphere extratropical cyclones. Climate Dyn., 9(3), 131-145.

King, J. C. and J. Turner. 1997. Antarctic meteorology and climatology. Cambridge,
Cambridge University Press.

Mayewski, P. A. and 13 others. 1994. Changes in atmospheric circulation and ocean ice cover over the North Atlantic during the last 41,000 years. Science, 263(5154), 1747-1751.

McMorrow, A. J., M. A. J. Curran, T. D. van Ommen, V. I. Morgan, M. A. J. Pook and I. Allison. 2001. Intercomparison of firn core and meteorological data. Antarct. Sci., 13(3), 329-337.

Morgan, V. I., C.W. Wookey, Li Jun, T. D. van Ommen, W. Skinner and M. F. Fitzpatrick. 1997. Site information and initial results from deep ice drilling on Law Dome, Antarctica. F. Glaciol., 43(143), 3-10.

Schwerdtfeger, W. 1984. Weather and climate of the Antarctic. Amsterdam, Elsevier. (Developments in Atmospheric Science 15.)

Steffensen, J. P., H. B. Clausen and J. M. Christensen. 1996. On the spatial variability of impurity content and stable isotopic composition in recent Summit snow. In Wolff, E.W. and R. C. Bales, eds. Chemical exchangebetween the atmosphere and polar snow. Berlin, etc., Springer-Verlag, 607-615. (NATO ASI Series I: Global Environmental Change 43.

Van Ommen, T. D., V. I. Morgan, T. H. Jacka, S. Woon and A. Elcheikh. 1999. Near-surface temperatures in the Dome Summit South (Law Dome, East Antarctica) borehole. Ann. Glaciol., 29, 141-144.

Vuille, M., D. R. Hardy, C. Braun, F. Keimig and R.S. Bradley. 1998. Atmospheric circulation anomalies associated with 1996/1997 summer precipitation events on Sajama Ice Cap, Bolivia. 7. Geophys. Res., 103(D10), 11,191-11,204 